\title{
Street food in Espírito Santo, Brazil: a study about good handling practices and food microbial quality
}

\author{
Auriane Morellato FERRARI ${ }^{1}$, Jhenifer de Souza Couto OLIVEIRA ${ }^{1}$, Jackline Freitas Brilhante de SÃO JOSÉ $1,2 \star$ (D)
}

\begin{abstract}
Street foods are points of sale of ready-to-eat foods sold on the public roads. However, due to the conditions of handling and sale of food practiced in these trades, these can pose risks to public health. This study aimed to evaluate the conditions of the handling and sale of food from street vendors in Vitória and Serra, Espírito Santo, Brazil. A checklist based on the Brazilian legislation resolution number 216/2004 was used to verify the sanitary conditions of the trades. In addition, samples of foods commercialized in these trades were collected to determine microbiological quality, according to current legislation. Of the 200 trades evaluated, $58.5 \%$ were classified as "Poor," with unsatisfactory hygiene conditions. The main inadequacies were related to the hygienic conditions of the seller. Of the 63 food samples analyzed, $57.1 \%$ presented contamination above the limit allowed by the legislation and were as a result considered unfit for consumption. It has been concluded that street vending is still a potential source of pathogens that cause foodborne illness.
\end{abstract}

Keywords: food quality; street food; food hygiene practices; microbial contamination; food safety.

Practical Application: The assessment of the good handling practices and microbial quality in street food from cities of Espírito Santo, Brazil indicated that street-vending food is a source of risk to consumer health and this should be considered as a public health issue.

\section{Introduction}

Street-vending food, or street food, is characterized as food or drinks sold on streets and consumed without any further preparation (World Health Organization, 1996). These trades have adept consumers in all regions of the world and are selling can express more than just the meal, revealing aspects of local culture and gastronomy of different locations (Abrahale et al., 2019). It is estimated that approximately 2.5 million people consume food in these trades daily (Kothe et al., 2016). Selling food on the streets has benefits for sellers and consumers: people start marketing food as a source of income that helps the home economy. In other cases, it contributes to the survival of families in financial difficulties (Abrahale et al., 2019). For consumers, elements such as practicality, accessibility, the variety of options, appreciable palatability, and affordable price are attractive, considering the moment of choice for this kind of meal (Asiegbu et al., 2016; Cortese et al., 2016; Gupta et al., 2018; Soon, 2019).

In many of these street food trades, conditions of production and sale are verified as having empirical handling practices, poor hygiene practice, inadequate infrastructure and lack of potable water points (Amare et al., 2019; Chávez-Martinez et al., 2019; Garayoa et al., 2017; Samapundo et al., 2016). Therefore, street foods cause great concern among agencies involved in food safety (Trafialek et al., 2017) and is generally associated with foodborne illnesses, known to be an important global public health problem
(Asiegbu et al., 2016; Chávez-Martinez et al., 2019; Mali et al., 2019; Trafialek et al., 2017, 2018; Soon, 2019). In addition, this is strongly associated with the lack of hygienic and sanitary control in food production processes, such as hand hygiene and handling (Abrahale et al., 2019; Mali et al., 2019; Tomar \& Akarca, 2019).

Although government agencies have concerns regarding food contamination, the attitudes related to their prevention are still insubstantial, with few sanitary education measures and low control by regulatory organizations (Tabrizi et al., 2017). Due few public policies and actions to inspect street food, most vendors may end up not following specific regulations and, therefore, food safety may not be guaranteed (Chávez-Martinez et al., 2019). Data on the sanitary conditions of street-vended food in Espírito Santo, as well as microbiological food quality, are still scarce. Therefore, the aim of this study was to analyze the food handling conditions and the microbial quality of street-vended food in municipalities of Espírito Santo, Brazil.

\section{Materials and methods}

The study was carried out to evaluate good handling practices and the microbiological quality of commercialized foods. All steps were performed between October 2017 and August 2018. The selection of municipalities was based on the population number and economic importance for Espírito Santo state in Brazil. As a result, Vitória and Serra were chosen. Vitória is the

${ }^{1}$ Programa de Pós-graduação em Nutrição e Saúde, Centro de Ciências da Saúde, Universidade Federal do Espírito Santo - UFES, Campus Maruípe, Vitória, ES, Brasil ${ }^{2}$ Curso de Nutrição, Departamento de Educação Integrada em Saúde, Universidade Federal do Espírito Santo - UFES, Campus Maruípe, Vitória, ES, Brasil

*Corresponding author: jackline.jose@ufes.br 
capital of the state and a city with a great circulation of people, and Serra is the most populous city of Espírito Santo.

Since street vending is a trade modality that is typically informal, a non-probabilistic sample was used, visiting points with a great flow of people, such as the center of each municipality, plazas, areas around hospitals, universities, schools, and on the beachfront. All trades were visited during their business hours, both during the day and night shift, from Monday to Sunday. No trade was notified prior to the survey. The researchers stayed at each location to identify the maximum number of street-food trades/vendors willing to participate in the study and only moved on to another location after the hawkers had exhausted trade in a location.

The sampling choice was based on the production of food, the amount of handling, exposure of products for sale and availability in the market. Industrialized products, foods with few steps of handling, and foods that do not require special storage temperatures (cold or heat) or storage equipment that need hygiene to undergo a hygiene process were excluded. The foods selected were hotdogs, savory snacks, coconut water (that needed equipment for conditioning and/or cooling), boiled corn and barbecued meat on skewers.

The Ethics and Research Committee of the Federal University of Espírito Santo, under protocol number 2.091.122, approved this study. All participants signed a Free and Informed Consent Form prior to the survey.

\subsection{Evaluation of good handling practices}

Data were collected with the use of a structured checklist consisting of 37 items based on the Collegiate Board Resolution (RDC) No. 216/2004 of the Brazilian Health Regulatory Agency (Brasil, 2004). The list applied through observation and questions to the handler, was separated into two parts. The first part characterized the trade. The second part evaluated the hygienic-sanitary conditions of the trade and was divided into five blocks: 1. Physical structure (conditions of the street-vended vehicle, equipment, and utensils evaluated); 2 . Food handlers/ vendors (evaluation of personal and hand hygiene, the presence of an illness that may contaminate food); 3. Handling practices (conduct in handling food, ingredients and raw materials used, storage of raw and ready-to-eat foods, exposure of the prepared food); 4. Environmental conditions (observation around points of sale and trash can); and, 5. The presence of a sanitary license and exposure of the document to the consumer. All the items had three answer possibilities: "C" for conforming items; "NC" for non-conforming items; and "NA" when the item was not applicable to the trade. After the checklist, the answers were computed, and the trades were classified in general and by blocks according to the percentage of suitability recommended by the RDC No. 275/2002 (Brasil, 2002). Street food trades were classified as "Good" when they got between 76 and $100 \%$ of compliance, "Regular" when they obtained between 51 to $75 \%$, and "Poor" when they were equal or below $50 \%$ of compliance. All items marked as "not applicable" were excluded from computing the results to calculate the adequacy of the trade.

\subsection{Sampling and microbiological analysis}

All foods were purchased and with the maximum amount of ingredients available to the consumer. The food was collected during business hours, on a day other than the day the checklist was applied. The sampling unit was composed of two units of the same product per point of sale. The researchers responsible for collecting the samples went to the trade and purchased the product. The food purchased was collected in the seller's packaging in order to detect all possible sources of food contamination. The samples were stored at $7^{\circ} \mathrm{C} \pm 1{ }^{\circ} \mathrm{C}$ for a maximum of 24 hours, and the microbiological analyses were conducted at the microbiology laboratory.

The procedures applied in this step were performed according to the methodology of the American Public Health Association (APHA), described in the Compendium of Methods for the Microbiological Examination of Foods (American Public Health Association, 2001). The investigation of the microorganisms in this study followed the recommendations of the Brazilian legislation RDC No. 12/2001 (Brasil, 2001). Analyses were conducted to detect the presence of Salmonella sp., and to quantify Staphylococcus aureus, Escherichia coli, and coliforms at $35^{\circ} \mathrm{C}$ for all investigated foods. The results were described in colony forming units per gram $(\mathrm{CFU} / \mathrm{g})$ or milliliters $(\mathrm{CFU} / \mathrm{mL})$.

\subsection{Statistical analysis}

The data were tabulated in Microsoft Excel and analyzed in IBM SPSS Statistics version 22.0. The results were described using simple descriptive frequency analysis and proportions for the categorized data. The results of the microbiological analyses were compared with the current Brazilian legislation, RDC No. 12/2001 (Brasil, 2001), when conducting the study.

\section{Results and discussion}

\subsection{Evaluation of good practices for the handling of street vending}

In this study, 200 street vending participated. From this total, $54.5 \%(n=109)$ were located in the city of Vitória and $49.5 \%$ $(n=99)$ had only one employee to perform all activities, from handling, sales, and site hygiene. One hypothesis to justify the limited number of labor is the costs that come with this service. This situation is a characteristic of this type of trade that can compromise the quality of food since there is no separation between distinct operations involving food handling, money handling, sanitation processes, and garbage collection (Samapundo et al., 2016). According to RDC No. 216/2004, people who handle food should not manage money or carry out hygiene processes at the same time (Brasil, 2004).

Among the sold products, coconut water and barbecued meat on skewers were the most commercialized products, present in $28.5 \%(n=57)$ and $26.0 \%(n=52)$ of the trades visited, respectively (Table 1). According to Imathiu (2017), the kinds of food sold on the streets vary according to local culture, taste and customer preference. The state of Espírito Santo is a location with a humid tropical climate, with average temperatures of $25^{\circ} \mathrm{C}$ 
(Espírito Santo, 2018). Therefore, a widespread consumption of beverages that can refresh and hydrate consumers is expected, justifying the predominance of coconut water sales.

Regarding the general compliance of the trades with the verified items in the checklist, $58.5 \%(\mathrm{n}=117)$ were classified as "Poor" while $3.5 \%(n=7)$ were classified as "Good". The evaluation by blocks found that the classification described as "Poor" was categorized, as follows: $49.0 \%$ for physical structure; $83.0 \%$ for block of food handlers/vendors; $45.5 \%$ for handling

Table 1. Characterization of street food trades in the municipalities of Vitória and Serra, Espírito Santo, Brazil.

\begin{tabular}{lrc}
\hline \multicolumn{1}{c}{ Variable } & n & \% \\
\hline Local & 109 & 54.5 \\
Vitória & 91 & 45.5 \\
Serra & & \\
Product & 34 & 17.0 \\
Hot-dogs/sandwich & 48 & 24.0 \\
Savory snacks & 57 & 28.5 \\
Coconut water & 9 & 4.5 \\
Boiled corn & 52 & 26.0 \\
Barbecue skewer & & \\
Number of employees & 99 & 49.5 \\
1 & 74 & 37.0 \\
2 & 27 & 13.5 \\
\hline
\end{tabular}

$\mathrm{n}=$ absolute frequency; $\%=$ relative frequency. practices; $87.5 \%$ for environment conditions; and $85.5 \%$ for sanitary licensing (Figure 1).

Other studies, both Brazilian and international, have also pointed out significant failures in the application of good handling practices among street vendors (Adimasu et al., 2016; Liu et al., 2014; Magalhães et al., 2016; Proietti et al., 2014; Samapundo et al., 2015, 2016; Trafialek et al., 2017). One of the most important steps in preventing food contamination, reducing, or eliminating possible food pathogens, is the adequate hygienic practice of the food handler (Tomar \& Akarca, 2019). Therefore, this result reveals the high exposure of food to contamination and the increased risk of acquiring foodborne diseases by the consumer.

Concerning the physical structure block, $62.6 \%(n=125)$ of non-compliances were recorded regarding the hygiene of equipment and utensils before and after use. Another observed situation was the reuse of utensils without first performing the correct hygiene processes. The continuous and frequent use of equipment and utensils used in the handling and sale of food increases the risks of contamination, especially from the possible adhesion of particles that are difficult to remove (Schirone et al., 2018). Loukieh et al. (2018) found that only $6.7 \%$ of street trading visited in Beirut, capital of Lebanon, used different utensils to handle different types of food (raw, cooked, clean and unclean). Good handling practices recommend avoiding direct or indirect contact between raw and cooked products to ensure food safety (Brasil, 2004). Thus, this practice clearly shows that majority of trades do not pay attention to the prevention of cross-contamination between foods.

For $40.5 \%(n=81)$ of the trades, the equipment and utensils presented surfaces with signs of oxidation and corrosion, poor state of conservation and hygiene, in addition to residue accumulation. Surfaces of equipment and utensils must be smooth, washable,

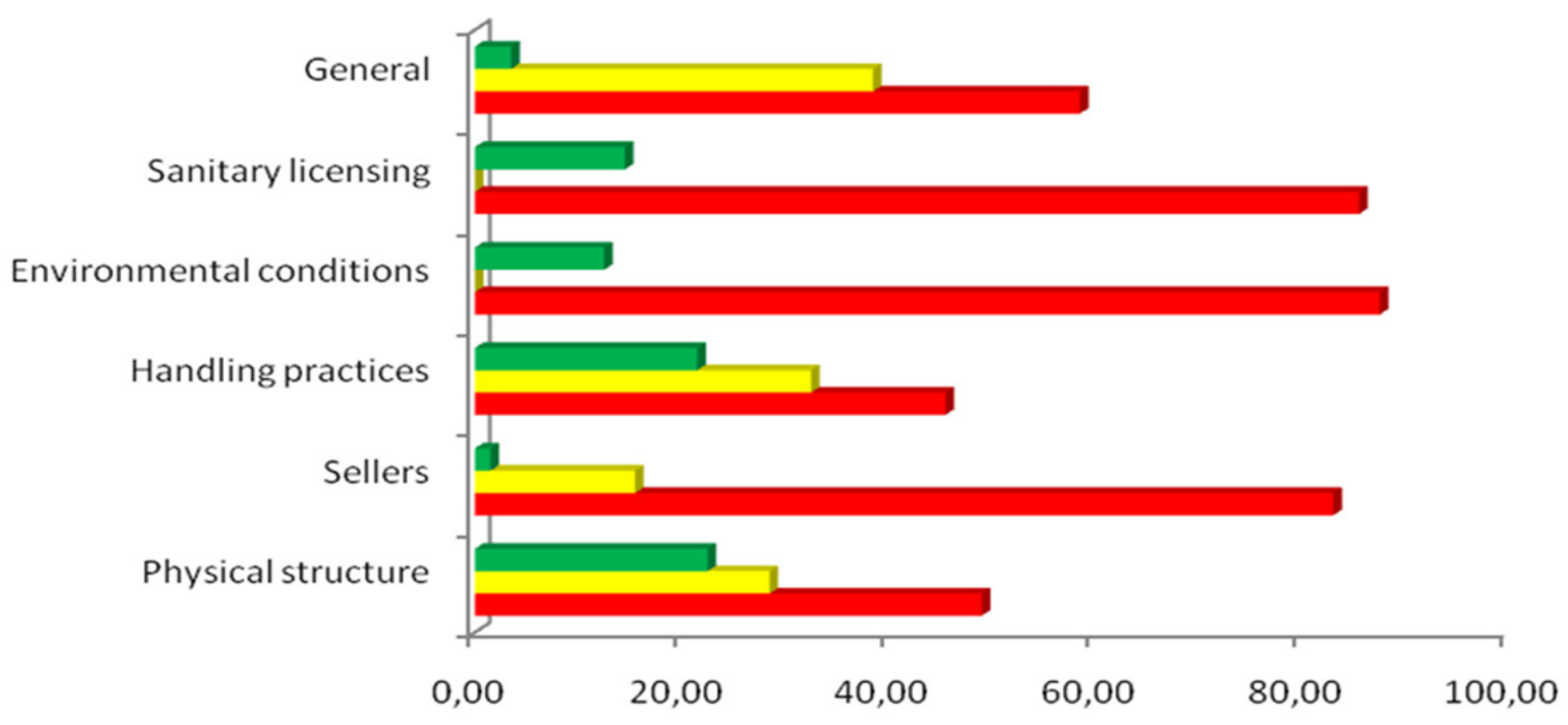

Figure 1. Classification street food trades in the municipalities of Vitória and Serra - ES. 
impermeable, free from conditions that impact hygiene, be in good repair condition, and clean. When they come in contact with food, these surfaces must not transmit toxic substances, they must be resistant to corrosion and undergo several cleaning and disinfection procedures (Brasil, 2004). If these conditions are missing proper sanitation, the food is compromised. Food contact surfaces that are not properly sanitized can favor the microbial growth and contribute strongly to food contamination (Tomar \& Akarca, 2019).

In $47.5 \%$ ( $n=95)$ of trades, especially for hot dogs and savory snacks, there was no adequate equipment for temperature control, or they were in a poor state of conservation and functioning. Such foods are very perishable as they undergo several stages of handling and require temperature-controlled storage (Kothe et al., 2016). Storing food in inadequate temperatures may increase the risk of food contamination, promoting the survival and spread of spoilage and pathogenic bacteria. It is recommended to store cold preparations such as fillings, sauces, and raw foods at temperatures up to $8{ }^{\circ} \mathrm{C}$. For hot foods, such as barbecued meat on skewer, savory snacks, boiled corn, and some hot dog fillings, the temperature of storage should be $60{ }^{\circ} \mathrm{C}$ or more for a maximum of 6 hours (Brasil, 2004; Garayoa et al., 2017; Nogueira et al., 2019).

In the seller block, hand hygiene was responsible for the highest percentage of inadequacy $(96.0 \%, n=192)$. Of the total inadequate trades, $100.0 \%$ did not use detergent to sanitize their hands, and $83.0 \%(\mathrm{n}=138)$ did not use a sanitizing product. Hands not correctly sanitized are one of the main vehicles of food contamination, especially by the oral-fecal mechanism (Samapundo et al., 2016). Other studies also detected low adherence to proper hand hygiene among street vendors (Adimasu et al., 2016; Cortese et al., 2016; Kothe et al., 2016; Loukieh et al., 2018; Magalhães et al., 2016; Samapundo et al., 2015, 2016). Brazilian legislation establishes the technique and the appropriate frequency for handwashing: it is necessary to use water, liquid soap and rub the hands with an antiseptic agent when starting activities, before and after handling food. After any service interruption, such as touching contaminated materials or parts of the body, handling money, using the toilets, and whenever necessary, this hygiene process must be repeated (Brasil, 2004).

In addition, $97.5 \%(n=195)$ of the trades did not have potable water points. Due to their poor physical structure, often the installation of water points becomes unfeasible. This peculiar characteristic of street vending affects the quality of the meal since it makes the hand's hygiene difficult and contributes to the non-adherence of vendors to the appropriate procedure. Structural difficulties also mean that there are no necessary supplies such as water and liquid soap for sanitation to occur (Liu et al., 2014; Proietti et al., 2014). In Beirut, Lebanon, an adequate structure for hand washing was present only in $26.7 \%$ of street food stalls (Loukieh et al., 2018). Consequently, this reason contributes to the inadequate hand hygiene of these street vendors.

Inappropriate hygiene may favor the survival of pathogenic bacteria such as Salmonella and Escherichia coli (World Health Organization, 1989). In situations where vendors do not perform the hand washing procedure during handling and marketing (handling of money, waste and utensils). The food handler can cause its contamination, as the hands are important vehicles for the transfer of organisms from the feces, nose and skin to the food (Amare et al., 2019; Loukieh et al., 2018).

The adequate use of gloves was not verified in $76.5 \%(n=153)$ of the trades. On the other hand, $64.5 \%(n=129)$ of the trades were inadequate regarding the wearing of adornments, such as jewelry, while $66.0 \%(n=132)$ wore inappropriate clothing. The low adhesion to wearing gloves found in this study corroborates the results described by Loukieh et al. (2018), Samapundo et al. $(2015,2016)$. Proper glove use associated with frequent use of a sanitizing agent could be a measure to reduce the risk of contamination by hands. However, it is necessary to change the gloves often, which would lead to increased costs for street vendors (Samapundo et al., 2016).

As for the clothing, a similar result was found by Loukieh et al. (2018), in that vendors did not wear clothes that were appropriate to the activity and they wore adornments. It is important that every foodhandler wear clothing appropriate to the activity conducted and do not wear jewelry ornaments, since this tends to increase the chances of contamination and decrease the effectiveness of hygiene (Garayoa et al., 2017).

In the block of handling practices, the use of mayonnaise and artisanal sauces registered $51.5 \%(\mathrm{n}=103)$ of non-compliance, of which $74.7 \%(\mathrm{n}=77)$ used raw eggs as an ingredient. In $46.0 \%$ $(n=92)$ of the trades, the foods were not stored at the appropriate time and temperature to prevent microbial growth. The results from Cortese et al. (2016) in Florianópolis, Brazil differ from the results of this research, as they found only $14.0 \%$ of trades selling products with mayonnaise and sauces prepared at home, while all reported avoiding egg preparation. Handmade mayonnaise using ingredients such as raw eggs is a potential source of microorganisms such as Salmonella spp. (Shiningeni et al., 2019). A safe food requires that the ingredients used are not sources of contamination (Brasil, 2004). Moreover, products such as mayonnaise and sauce contain high humidity and water activity, so even if correctly handled, storing them at unsuitable temperatures favors microbial growth (Shiningeni et al., 2019). Inadequate temperature throughout the food-handling chain is one of the major factors responsible for foodborne illness (Garayoa et al., 2017).

In $46.5 \%(n=93)$ of the trades, there were no specific or identified sanitizing products stored properly and away from food. Using water and detergent only for cleaning equipment, utensils and the physical structure does not reduce the microbial load accumulated in these places, especially those that form biofilms. For that reason, it is necessary to use sanitizers associated with appropriate application techniques (Schirone et al., 2018). Brazilian legislation recommends that the hygiene of equipment, surfaces and utensils be carried out with the presence of water, detergent and sanitizing agents regulated by the Ministry of Health. In order not to become sources of contamination, chemical agents should be stored away from food, ingredients, and raw food materials (Brasil, 2004).

Regarding the block of environmental conditions, in 85.0\% $(\mathrm{n}=170)$ of the trades, the trash cans were nonexistent or inadequate, without lids or made from materials such as wood 
and cardboard. Similar results were described by Monteiro (2015) and Samapundo et al. $(2015,2016)$. Trash cans that do not have adequate hygiene standards can expose the waste to the environment and attract insects, rodents and other animals to the place, all of which are potent transmitters of pathogens (Samapundo et al., 2016). The nearby location of public roads, dust and trash around the trade resulted in $67.5 \%(\mathrm{n}=135)$ of inadequacies. The place of commercialization is a critical point for the possible contamination of street food since it can present unsatisfactory environmental conditions and attract insects and rodents (Cortese et al., 2016; Loukieh et al., 2018). Due to the high risk of environmental contamination and the absence of running water or potable water storage, the food safety conditions in these locations are impractical (Proietti et al., 2014). Food-vending sites without the accumulation of trash, insects and rodents indicate good hygiene conditions that allow the prevention of contamination and, consequently, contribute to the protection of consumer health.

Only $37.0 \%(n=74)$ of the evaluated trades reported having sanitary licensing. However, it was not possible to verify the accuracy of the information in $86.0 \%(n=64)$ of these, since the document was not available to the public. Other results in the literature corroborate with this study regarding the lack of sanitary licensing (Ma et al., 2019; Mali et al., 2019). The presence of a sanitary license, as well as the provision of the document, made visible to consumers, may demonstrate that the street vendor is concerned with regularization and seeks to meet hygienic and sanitary standards for food handling and marketing.

\subsection{Microbiological quality of foods sold by street vendors}

A total of 63 samples of foods sold in the street were analyzed, and $31.7 \%(n=20)$ corresponded to the barbecued meat on skewer, due to the higher commercialization of this product in the cities studied. Of the total samples, 57.1\% $(n=36)$ did not obtain the microbiological standard established in the current Brazilian legislation and were considered unfit for consumption. The behavior of vendors in the face of handling practices may have contributed to the low microbiological quality of the commercialized foods evaluated in the present study. Other studies have associated poor microbiological quality of food as a consequence of poor hygiene in the handling and sale of food (Barbosa et al., 2016; Loukieh et al., 2018). All kinds of food collected had at least one sample with the microbiological load above that allowed by the Brazilian legislation. Hot dog, the most handled sample, was the food with the highest contamination per sample $(87.5 \%, \mathrm{n}=7$ ) (Table 2). Other studies show results similar to those found in the present study regarding the low microbiological quality of food from the street vendors (Ababio \& Lovatt, 2015; Adimasu et al., 2016; Amare et al., 2019; Eromo et al., 2016; Kharel, Palni, \& Tamang, 2016; Loukieh et al., 2018).

The Brazilian legislation establishes as the microbiological limit for foods analyzed in this study counts $<10^{3} \mathrm{CFU} / \mathrm{g}$ for Staphylococcus aureus, $<10^{2} \mathrm{CFU} / \mathrm{g}$ for Escherichia coli, and absence of Salmonella sp. in $25 \mathrm{~g}$ of the food. In the case of liquid foods, such as coconut water, the standard is described in CFU/mL (Brasil, 2001). The same legislation does not define limit counts for coliforms at $35^{\circ} \mathrm{C}$. However, it is important to evaluate the count of this microbial group in the food because it is related to the implementation of good handling practices (Loukieh et al., 2018). According to Kharel et al. (2016), counts above $10^{5} \mathrm{CFU} / \mathrm{g}$ for total coliforms in foods indicate a health risk. In the present study, samples of savory snacks, coconut water, meat barbecued on skewer, and boiled corn showed counts equal to or greater than this limit and were therefore considered unfit for consumption.

The microorganisms Staphylococcus aureus and E. coli were present in all food varieties analyzed, with the highest counts being $3.51 \times 10^{6} \mathrm{CFU} / \mathrm{g}$ and $1.15 \times 10^{5} \mathrm{CFU} / \mathrm{g}$, respectively. Salmonella spp. was found in $6.3 \%(\mathrm{n}=4)$ of the samples, 1 of hot dogs and 3 of savory snacks. All savory snacks contaminated with Salmonella sp. were fried. Elevated temperatures above $60^{\circ} \mathrm{C}$ to which these foods are subjected are expected to be sufficient to eliminate the pathogenic microorganisms analyzed in that study (Garayoa et al., 2017; Kotzekidou, 2013). Thus, it is possible to presume that such foods have undergone cross-contamination or recontamination after frying. Hot dogs contained the sauces used to assemble them. These were produced from raw eggs, an ingredient considered to be of high contamination risk of pathogens such as Salmonella and E. coli. (Shiningeni et al., 2019). Overhandled foods such as hot dogs and savory snacks, are subject to increased risk of contamination during their

Table 2. Microbial counts interval of the food samples marketed in the street-vending food of Vitória and Serra, Espírito Santo, Brazil.

\begin{tabular}{|c|c|c|c|c|c|c|}
\hline Food & n (\%) & S. aureus $(\mathrm{CFU} / \mathrm{g})$ & $\begin{array}{c}\text { Coliforms } 35^{\circ} \mathrm{C} \\
(\mathrm{CFU} / \mathrm{g})\end{array}$ & E. coli $(\mathrm{CFU} / \mathrm{g})$ & $\begin{array}{l}\text { Salmonella sp. } \\
\quad(25 \mathrm{~g})\end{array}$ & $\begin{array}{c}\text { Inappropriate } \\
\text { samples according } \\
\text { to legislation }{ }^{1} \mathbf{n}(\%)\end{array}$ \\
\hline Savory snacks & $16(25.4)$ & n.d. $-3.51 \times 10^{6}$ & n.d. $-1.32 \times 10^{5}$ & n.d. $-1.15 \times 10^{5}$ & Present & $8(50.0)$ \\
\hline Hot-dog/sandwich & $8(12.7)$ & n.d. $-1.54 \times 10^{6}$ & $3 \times 10^{2}-7.65 \times 10^{4}$ & n.d. $-1.40 \times 10^{4}$ & Present & $7(87.5)$ \\
\hline Coconut water ${ }^{2}$ & $15(23.8)$ & n.d. $-3.50 \times 10^{4}$ & $10^{2}-2.65 \times 10^{5}$ & n.d. $-5 \times 10$ & Absent & $5(33.3)$ \\
\hline Boiled corn & $4(6.3)$ & $1.50 \times 10^{4}$ & n.d $-1.25 \times 10^{7}$ & $1.15 \times 10^{2}$ & Absent & $3(75.0)$ \\
\hline
\end{tabular}

${ }^{1}$ Comparison with the standards established by Brazilian legislation RDC No. 12/2001 (Brazil, 2001). ${ }^{2}$ For microbiological counts of coconut water, read UFC/mL; $\mathrm{n}=$ absolute frequency; $\%=$ relative frequency; n.d.: not detected at the lowest dilution. 
production chain. Therefore, they are potential sources of microbial contamination (Campos et al., 2015). In addition, ready-to-eat food can easily be contaminated again because of general poor hygiene, such as unclean preparation sites or cleaning utensils, cross-contamination, and inadequate personal hygiene, which were detected in the present study (Niyonzima et al., 2017). Boiled corn presented greater counts of $S$. aureus, which indicates failure of good hygiene practices in the handling or contamination of the packaging used.

The coconut water presented higher contamination with Coliforms at $35{ }^{\circ} \mathrm{C}$. It is presumed, therefore, that instances of failure in the processes of good hygiene practices of equipment, bottling and commercialization may have occurred. The quality of coconut water marketed on public roads, which use packaging equipment and are bottled manually, has also been questioned in other studies in Brazil (De Jesus et al., 2018; Silva et al., 2017).

According to Paudyal et al. (2017), the microorganisms most found in contaminated foods are enterobacteria, Escherichia coli, Salmonella spp., and Staphylococcus aureus. Staphylococcus aureus is a microorganism that inhabits the skin, hands, respiratory region, and superficial wounds, and is, therefore, an important indicator of hygiene behavior (Adjrah et al., 2013; Tomar \& Akarca, 2019). Studies have revealed the contamination of handlers by this microorganism in Vitória (Macedo et al., 2016), and in fresh fruit juices (Sabbithi et al., 2017). There is a high risk when this pathogen reaches counts higher than $10^{5}$ in foods, producing stable staphylococcal enterotoxins and serious health problems (Kharel et al., 2016; Kothe et al., 2016). In this study, the presence of $S$. aureus enterotoxins was not evaluated but counts above $10^{5}$ were found in savory snacks, hot dogs and meat barbecued on skewer samples, which indicates a potential risk to public health.

Escherichia coli is considered an important enterobacterium. Its presence in food is used as an indicator of fecal contamination and low hygienic conditions in food handling, especially hand hygiene, cross-contamination through utensils, and contact between raw and ready-for-consumption materials. For that reason, it should not be present in ready-to-eat foods (Shiningeni et al., 2019), since their ingestion can cause diarrhea and dysentery (Mehboob \& Abbas, 2019).

As for Salmonella spp., other results support those found in this study (Cardinale et al., 2015; Roger et al., 2015). Salmonella spp. is an important microorganism that inhabits the gastrointestinal region of animals and humans and can cause severe problems related to intestinal infection (Shiningeni et al., 2019). As it is are sensitive to heat, its presence in cooked foods indicates inadequate cooking temperatures or cross-contamination between raw and cooked foods (Cardinale et al., 2015). According to the same authors, contamination by Salmonella sp. is common in street-vending food due to the precariousness of the physical structure of the trade. Furthermore, early food preparation and lack of storage temperature control also contribute to contamination. Such conditions were found in this study and may consequently be associated with the contamination observed in the microbiological analyses. The presence of pathogens in the analyzed samples indicates that the food handlers failed in the preparation steps. In addition, it indicates a risk to which consumers are exposed. Implementing good handling practices and training food handlers can improve product compliance and, consequently, consumer safety (Chávez-Martinez et al., 2019).

This study had no interest in discouraging the consumption of such foods by the population, but rather sought to encourage data to elucidate pre-existing concepts and to build adequate public policies.

\section{Conclusion}

Thus, it can be assumed that street-vending food is a source of risk to consumer health and should be treated as a public health issue, involving educational and enforcement strategies to reduce risks.

\section{Acknowledgements}

This study was financed in part by the Coordenação de Aperfeiçoamento de Pessoal de Nível Superior - Brazil (CAPES) - Finance Code 001. We thank CAPES (Coordenação de Aperfeiçoamento de Pessoal de Nível Superior) for a scholarship of the second author and for the supporting the PostGraduate Program in Nutrition and Health of Federal University of Espírito Santo. We thank Pró-Reitoria de Extensão of Federal University of Espírito Santo for all support.

\section{References}

Ababio, P. F., \& Lovatt, P. (2015). A review on food safety and food hygiene studies in Gana. Food Control, 47, 92-97. http://dx.doi. org/10.1016/j.foodcont.2014.06.041.

Abrahale, K., Sousa, S., Albuquerque, G., Padrão, P., \& Lunet, N. (2019). Street food research worldwide: a scoping review. Journal of Human Nutrition and Dietetics, 32(2), 152-174. http://dx.doi.org/10.1111/ jhn.12604. PMid:30311276.

Adimasu, A., Mekonnen, B., Guadu, T., Gizaw, Z., \& Adane, T. (2016). Bacteriological quality assessment of selected street foods and their public health importance in Gondar Town, North West Ethiopia. Global Veterinaria, 17(3), 255-264. http://dx.doi.org/10.5829/idosi. gv.2016.17.03.10551.

Adjrah, Y., Soncy, K., Anani, K., Blewussi, K., Karou, D. S., Ameyapoh, Y., de Souza, C., \& Gbeassor, M. (2013). Socio-economic profile of street food vendors and microbi-ological quality of ready-to-eat salads in Lomé. International Food Research Journal, 20(1), 65-70.

Amare, A., Worku, T., Ashagirie, B., Adugna, M., Getaneh, A., \& Dagnwe, M. (2019). Bacteriological profile, antimicrobial susceptibility patterns of the isolates among street vended foods and hygienic practice of vendors in Gondar town, Northwest Ethiopia: a cross sectional study. BMC Microbiology, 19, 120. https://dx.doi.org//10.1186/ s12866-019-1509-4.

American Public Health Association - APHA. (2001). Compendium of methods for the microbiological examination of foods (4rd ed). Washington: APHA.

Asiegbu, C. V., Lebelo, S. L., \& Tabit, F. T. (2016). The food safety knowledge and microbial hazards awareness of consumers of ready-to-eat street-vended food. Food Control, 60, 422-429. https://doi.org/10.1016/j.foodcont.2015.08.021.

Barbosa, L. J., Ribeiro, L. F., Lavezzo, L. F., Barbosa, M. M., Rossi, G. A., \& do Amaral, L. A. (2016). Detection of pathogenic Escherichia coli and microbiological quality of chilled shrimp sold 
in street markets. Letters in Applied Microbiology, 62(5), 372-378. http://dx.doi.org/10.1111/lam.12562. PMid:26960181.

Brasil. Agência Nacional de Vigilância Sanitária. (2001). Regulamento Técnico Sobre os Padrões Microbiológicos para Alimentos (Resolução RDC nº.12, de 02 de janeiro de 2001). Diário Oficial [da] República Federativa do Brasil.

Brasil. Agência Nacional de Vigilância Sanitária. (2002). Dispõe sobre o Regulamento Técnico de Procedimentos Operacionais Padronizados aplicados aos Estabelecimentos Produtores/Industrializadores de Alimentos e a Lista de Verificação das Boas Práticas de Fabricação em Estabelecimentos Produtores/Industrializadores de Alimentos (Resolução RDC no 275, de 21 de outubro de 2002). Diário Oficial [da] República Federativa do Brasil.

Brasil. Agência Nacional de Vigilância Sanitária. (2004). Dispõe sobre Regulamento Técnico de Boas Práticas para Serviços de Alimentação (Resolução RDC n² 216, de 15 de setembro de 2004). Diário Oficial [da] República Federativa do Brasil.

Campos, J., Gil, J., Mourão, J., Peixe, L., \& Antunes, P. (2015). Ready-toeat street-vended food as a potential vehicle of bacterial pathogens and antimicrobial resistance: an exploratory study in Porto region, Portugal. International Journal of Food Microbiology, 206, 1-6. https://doi.org/ 10.1016/j.ijfoodmicro.2015.04.016.

Cardinale, E., Abat, C., Bénédicte, C., Vincent, P., Michel, R., \& Muriel, M. (2015). Salmonella and Campylobacter contamination of ready-to-eat street-vended pork meat dishes in Antananarivo, Madagascar: a risk for the consumers? Foodborne Pathogens and Disease, 12(3), 197-202. http://dx.doi.org/10.1089/fpd.2014.1864. PMid:25764444.

Chávez-Martinez, A, Paredes-Montoya, P., Entería-Monterrubio, A-L., Corral-Luna, A., Lechuga-Valles, R., Dominguez-Viveros, J., Sánchez-Vega, R., \& Santellano-Estrada, E. (2019). Microbial quality and prevalence of foodborne pathogens of cheeses commercialized at different retail points in Mexico. Food Science and Technology, 39(2), 703-710. https://doi.org/10.1590/fst.30618.

Cortese, R. D. M., Veiros, M. B., Feldman, C., \& Cavalli, S. B. (2016). Food safety and hygiene practices of vendors during the chain of street food production in Florianopolis, Brazil: a cross-sectional study. Food Control, 62, 178-186. http://dx.doi.org/10.1016/j.foodcont.2015.10.027.

De Jesus, N. S., Valiati, T. B., Barcelos, I. B., Romão, N. F., Marson, R. F., \& Sobral, F. O. S. (2018). Avaliação microbiológica da água de coco comercializada no município de Ouro Preto do Oeste, Rondônia, Brasil. Revista Saúde e Desenvolvimento, 12(10), 173-182.

Eromo, T., Tassew, H., Daka, D., \& Kibru, G. (2016). Bacteriological quality of street foods and antimicrobial resistance of isolates in Hawassa, Ethiopia. Ethiopian journal of Health Sciences, 26(6), 533-542. http://dx.doi.org/ 10.4314/ejhs.v26i6.5. PMid:28450768.

Espírito Santo. Governo do Estado. (2018). Geografia. Retrieved from: https://www.es.gov.br/geografia

Garayoa, R., Abundancia, C., Díez-Leturia, M., \& Vitas, A. I. (2017). Essential tools for food safety surveillance in catering services: On-site inspections and control of high risk cross-contamination surfaces. Food Control, 75, 48-54. http://dx.doi.org/10.1016/j. foodcont.2016.12.032.

Gupta, V., Khanna, K., \& Gupta, R. K. A. (2018). study on the street food dimensions and its effects on consumer attitude and behavioural intentions. Tourism Review, 73(3), 374-388. http://dx.doi.org/10.1108/ TR-03-2018-0033.

Imathiu, S. (2017). Street vended foods: potential for improving food and nutrition security or a risk factor for foodborne diseases in developing countries? Current Research in Nutrition and Food Science Journal, 5(2), 55-65. http://dx.doi.org/10.12944/CRNFSJ.5.2.02.

Kharel, N., Palni, U., \& Tamang, J. P. (2016). Microbiological assessment of ethnic street foods of the Himalayas. Journal of Ethnic Foods, 3(3), 235-241. http://dx.doi.org/10.1016/j.jef.2016.01.001.

Kothe, C. I., Schild, C. H., Tondo, E. C., \& Malheiros, P. S. (2016). Microbiological contamination and evaluation of sanitary conditions of hot dog street vendors in Southern Brazil. Food Control, 62, 346350. http://dx.doi.org/10.1016/j.foodcont.2015.11.005.

Kotzekidou, P. (2013). Microbiological examination of ready-to-eat foods and ready-to-bake frozen pastries from university canteens. Food Microbiology, 34(2), 337-343. http://dx.doi.org/10.1016/j. fm.2013.01.005. PMid:23541200.

Liu, Z., Zhang, G., \& Zhang, X. (2014). Urban street foods in Shijiazhuang city, China: Current status, safety practices and risk mitigating strategies. Food Control, 41, 212-218. http://dx.doi.org/10.1016/j.foodcont.2014.01.027.

Loukieh, M., Mouannes, E., Jaoudeh, C. A., Wakim. L. H., Fancello, F, \& Zeidan, M. B. (2018). Street foods in Beirut city: an assessment of the food safety practices and of the microbiological quality. Journal of Food Safety, 38(3), e12455. https://doi.org/10.1111/jfs.12455.

Ma, L., Chen, H., Yan, H., Wu, L., \& Zhang, W. (2019). Food safety knowledge, attitudes, and behavior of street food vendors and consumers in Handan, a third-tier city in China. BMC Public Health, 19, 1, 1128. https://doi.org/10.1186/s12889-019-7475-9.

Macedo, V. F., Zanardo, J. G., Lopes, R. P. C., Mendonça, H. F. M. S., Raymundo, N. L. S., \& Moraes, R. (2016). Prevalência de coliformes e Staphylococcus aureus em mãos de manipuladores de alimentos de feira livre de Vitória-ES. Sallus Journal of Health Sciences, 2(2), 27-38. http://dx.doi.org/10.5935/2447-7826.20160014.

Magalhães, J. A., Carvalho, S. S., Melquiades, R., Rosa, G., \& Merlini, L. S. (2016). Comércio ambulante de alimentos: condições higiênicosanitárias nos pontos de venda no município de Umuarama, Paraná, Brasil. Arquivos de Ciências Veterinárias e Zoologia da UNIPAR, 19(3), 147-152. http://dx.doi.org/10.25110/arqvet.v19i3.2016.6087.

Mali, S. K., Haque, R., Sem, L. C., \& Debnath, S. (2019). Vendors and consumers status, water quality and microbial analysis of street side foods in Patuakhali district. International Journal of Health Sciences and Research, 9(12), 251-263.

Mehboob, A., \& Abbas, T. (2019). Evaluation of microbial quality of street food in Karachi City, Pakistan: an epidemiological study. Microbiology Research, 10(1), 1-7. http://dx.doi.org/10.4081/mr.2019.7463.

Monteiro, M. A. M. (2015). Caracterização do comércio ambulante de alimentos em Belo Horizonte-MG. Demetra: Alimentação, Nutrição \& Saúde, 10(1), 87-97. http://dx.doi.org/10.12957/demetra.2015.13364.

Niyonzima, E., Ongol, M. P., Brostaux, Y., Korsak Koulagenko, N., Daube, G., Kimonyo, A., \& Sindic, M. (2017). Consumption patterns, bacteriological quality and risk factors for Salmonella contamination in meat-based meals consumed outside the home in Kigali, Rwanda. Food Control, 73, 546-554. http://dx.doi.org/10.1016/j.foodcont.2016.09.004.

Nogueira, A. S., Pignata-Viana, M. C., \& Pignata, M. C. (2019). Evaluation of the temperature of distribution and analysis of critical control points on a self-service restaurant of the city of Guanambi-BA. Journal of Health Sciences, 21(2), 181-185. http://dx.doi.org/10.17921/24478938.2019v21n2p181-185.

Paudyal, N., Anihouvi, V., Hounhouigan, J., Matsheka, M. I., SekwatiMonang, B., Amoa-Awua, W., Atter, A., Ackah, N. B., Mbugua, S., Asagbra, A., Abdelgadir, W., Nakavuma, J., Jakobsen, M., \& Fang, W. (2017). Prevalence of foodborne pathogens in food from selected African countries-a meta-analysis. International 
Journal of Food Microbiology, 249, 35-43. https://doi.org/10.1016/j. ijfoodmicro.2017.03.002.

Proietti, I., Frazzoli, C., \& Mantovani, A. (2014). Identification and management of toxicological hazards of street foods in developing countries. Food and Chemical Toxicology, 63, 143-152. http://dx.doi.org/10.1016/j.fct.2013.10.047. PMid:24220610.

Roger, D. D., James, B., \& Bakari, D. (2015). Microbiological quality and safety of street meat-food sold in Soudano Sahelian zone of Cameroon. International Journal of Current Microbiology and Applied Sciences, 4(2), 441-450.

Sabbithi, A., Reddi, S. G. D. N. L., Naveen Kumar, R., Bhaskar, V., Subba Rao, G. M., \& Rao V, S. (2017). Identifying critical risk practices among street food handlers. British Food Journal, 119(2), 390-400. http://dx.doi.org/10.1108/BFJ-04-2016-0174.

Samapundo, S., Cam Thanh, T. N., Xhaferi, R., \& Devlieghere, F. (2016). Food safety knowledge, attitudes and practices of street food vendors and consumers in Ho Chi Minh city, Vietnam. Food Control, 70, 79-89. http://dx.doi.org/10.1016/j.foodcont.2016.05.037.

Samapundo, S., Climat, R., Xhaferi, R., \& Devlieghere, F. (2015). Food safety knowledge, attitudes and practices of street food vendors and consumers in Port-au-Prince, Haiti. Food Control, 50, 457-466. https://doi.org/10.1016/j.foodcont.2014.09.010.

Schirone, M., Visciano, P., Di Serafino, G., Tofalo, R., Ciccarelli, A., \& Suzzi, G. (2018). Assessment of knowledge and applications of hygiene practices in the food service sector. Journal of Food Safety, 38(4), e12457. http://dx.doi.org/10.1111/jfs.12457.

Shiningeni, D., Chimwamurombe, P., Shilangale, R., \& Misihairabgwi, J. (2019). Prevalence of pathogenic bacteria in street vended readyto-eat meats in Windhoek, Namibia. Meat Science, 148, 223-228. http://dx.doi.org/10.1016/j.meatsci.2018.05.014. PMid:29861289.
Silva, C. P. C., Oliveira, L. S., Silva, T. L., Andrade, J. A. Fo., \& Reis, I. A. O. (2017). Qualidade microbiológica de águas de coco (Cocus nucifera) comercializadas no município de Aracaju, SE. Interfaces Científicas - Saúde e Ambiente, 5(3), 57-66. https://doi.org/10.17564/2316-3798.2017v5n3p57-66.

Soon, J. M. (2019). Rapid Food Hygiene Inspection Tool (RFHiT) to assess hygiene conformance index (CI) of street food vendors. Lebensmittel-Wissenschaft + Technologie, 113, 108304. http://dx.doi. org/10.1016/j.lwt.2019.108304.

Tabrizi, J. S., Nikniaz, L., Sadeghi-Bazargani, H., Farahbakhsh, M., \& Nikniaz, Z. (2017). Determinants of the food safety knowledge and practice among Iranian consumers: a population-based study from northwest of Iran. British Food Journal, 119(2), 357-365. http://dx.doi.org/10.1108/BFJ-08-2016-0347.

Tomar, O., \& Akarca, G. (2019). Critical control points and food pathogen presence in dairy plants from Turkey. Food Science and Technology (Campinas), 39(2), 444-450. http://dx.doi.org/10.1590/fst.29717.

Trafialek, J., Drosinos, E. H., \& Kolanowski, W. (2017). Evaluation of street food vendors' hygienic practices using fast observation questionnaire. Food Control, 80, 350-359. http://dx.doi.org/10.1016/j. foodcont.2017.05.022.

Trafialek, J., Drosinos, E. H., Laskowski, W., Jakubowska-Gawlik, K., Tzamalis, P., Leksawasdi, N., Surawang, S., \& Kolanowski, W. (2018). Street food vendors' hygienic practices in some Asian and EU countries - a survey. Food Control, 85, 212-222. http://dx.doi.org/10.1016/j.foodcont.2017.09.030.

World Health Organization - WHO. (1989). Health principles of hoousing. Geneva: WHO.

World Health Organization - WHO. (1996). Essential safety requirements for street vended foods. Food safety unit. Geneva: WHO. 